\title{
Mineral Nutrition Status of Some Aromatic Plants Grown in Muğla, Determination of Their Soil Characteristics and Uses in the Kitchen
}

\author{
Selma Atabey ${ }^{(\mathbb{D})}$, Mahmut Yildiztekin ${ }^{(D)}$, , Atilla Levent Tuna ${ }^{(\mathbb{B} \text {, Okay Nazli }}{ }^{4}$, \\ Olcay Ceylan ${ }^{(i)}$, Ibrahim Yokas ${ }^{(D)} 1$
}

${ }^{1}$ Ortaca Vocational School, Muğla Sıtkı Koçman University, Muğla, Turkey

${ }^{2}$ Department of Herbal and Animal Production, Köycegiz Vocational School, Muğla Sitkı Koçman University, Köyceğiz, Muğla, Turkey

${ }^{3}$ Department of Biology, Faculty of Science, Muğla Sitkı Koçman University, Muğla, Turkey

${ }^{4}$ Department of General Surgery, Medical School, Muğla Sıtkı Koçman University, Muğla, Turkey

\begin{abstract}
In this study, mineral nutrition status of some aromatic plants such as Foeniculum vulgare, Cichorium intybus, Brassica oleracea var. capitata, Liquidambar orientalis that are naturally spread in Muğla province and its locality and consumed by the local people, and the soil characteristics of the species were investigated. According to the results, it was determined that the species of plants spread between $\mathrm{pH}$-mild acid and neutral in a loamy, salt-free and low-lime environment. In addition to this, while it was determined that plants were at high levels in terms of $\mathrm{N}, \mathrm{Ca}$ and Fe contents, $\mathrm{Zn}$ value was found to be at a low level. In the second phase of the study, it was aimed to obtain detailed information for above mentioned local plants by using qualitative research method. It was found that there were differences in the nutrition habits of the societies due to different cultures. Local differences mostly stemmed from the yields grown in that region. One another aim is to investigate the food preparations in Muğla cuisine preferred by the local people regarding "arapsaçı, hindiba, cibez and günlük" (TR), which are among the medicinal aromatic plants found in Muğla, and the consumption preferences of these plants. The main purpose of this research was to determine the aromatic plant consumption habits of the people living in Muğla province and evaluate these consumptions in terms of health. As a result of the interviews, the recipes of these dishes, information on their preferability and their effects on health were obtained.
\end{abstract}

\section{ARTICLE HISTORY}

Received: June 16, 2020

Revised: August 17, 2020

Accepted: September 02, 2020

\section{KEYWORDS}

Aromatic plants,

Gastronomy,

Mineral nutrition,

Regional cuisine

\section{INTRODUCTION}

The number of plant species spread in Turkey is close to the number of plant species spread in the whole European continent. Our country has a very rich flora in terms of existing plant diversity. The flora of our country consists of approximately 12.006 taxa [1]. The main reasons of how our flora is so rich are that our country is in a location where three different phytogeography regions in terms of climate and vegetation cover, briefly floristic structure,

CONTACT: Mahmut Yildiztekin $\square$ mahmutyildiztekin@mu.edu.tr $\equiv$ Department of Herbal and Animal Production, Köycegiz Vocational School, Muğla Sıtkı Koçman University, Muğla, Turkey 
intersect (which are: Europe-Siberia phytogeography in North Anatolia; Mediterranean phytogeography in West and South Anatolia; and Iran-Turan phytogeography in Central and South East Anatolia), that Anatolia is like a bridge between Europe and Asia continents and the diversity and reciprocal plant migration between the two continents increase accordingly, that Anatolia is the center of many different kinds and sections, and that edaphic (earth) factors are quite diverse [2]. In addition to this, with the rapid population growth and destruction of nature, some plants are endangered. Determining and protecting the life circuits, morphological and anatomical structures, habitat characteristics and soil plant diversity of these plants and culturing them is of great importance for the continuity of generations.

Taking certain minerals in proper portions in daily nutrition is one of the fundamental principles of healthy lifestyle. On the other hand, due to the fact that these elements are natural and used industrially, the existence of these elements over certain limit values may have negative effects on living beings [3]. Despite the fact that the insufficiency or high values of mineral nutrients cause serious health problems, sufficient amounts play an important role as micro/macro or beneficial elements in human metabolism [4].

Plants take many elements from the environment in which they grow so that they can continue their vital activities, grow and develop. However, some of these elements (about 20) are those that are extremely essential nutrients for plants. In addition to the parameters that are the subject of the study, selenium is an important nutrient for human and animal nutrition. Selenium is one of the fundamental trace elements involved in the 25 different selenoproteins with its various biological roles especially like antioxidant and anti-inflammatory agent [5]. Even if there are preliminary reports in the countries with high dietary selenium and rare selenium deficiency, it is possible that the effect of externally administered selenium on both cancer risk and cancer disease has been underestimated up until now [6]. Besides, due to its antioxidative effects, selenium contributes to plant growth and development, and yield quality [7]. Plants play a crucial role in Se transfer in the human food chain [8-10].

This study is of great importance in terms of examining the macro and micro nutrients and selenium levels of some edible plants that naturally spread in Muğla, which is deemed significant regarding human health and nutrition. Accordingly, the determination of the uses of these plants, the reasons of preferences by the local people and the detection of the mineral nutrients covered by these plants constituted the main subject of the study. In addition to this, with these plants which are intensively consumed in the region, it was aimed to form the source materials for future studies and contribute to the studies in such fields as health and gastronomy. Another purpose of this research was to determine the aromatic plant consumption habits of the people living in Muğla province and to evaluate this consumption in terms of health. Within the context of this purpose, the sub-problems of this research could be given as follows; (a) what kinds of dishes can be made with herbs, (b) whether their long-term uses are possible or not, (c) what benefits are expected from these products, (d) how often they are consumed, (e) what the effect of family members is in aromatic consumption habits, (f) what kind of plant nutrients exist in which plants, and (g) what the effects of the dishes and beverages made with these herbs are on health. It was also aimed to reveal the dishes made from the plants that were the subject of the research, record the forgotten cultural values, and draw attention to their importance in terms of both human health and gastronomy tourism.

\section{MATERIAL and METHODS}

\subsection{The Collection of the Plants and Analyses}

The localities of the plants in the research were determined by reviewing the data obtained from the preliminary examinations made in the book "Flora of Turkey" $[11,12]$ and the 
previous flora studies conducted in Muğla province. The scientific name, local name, locality and herbarium codes of the plant species presented in the study were given in Table 1 below.

Table 1. The botanization localities of plant materials

\begin{tabular}{|c|c|c|c|c|}
\hline The name of the species & Local name & Locality & Code name & Herbarium Code \\
\hline Foeniculum vulgare Mill. & Arapsaçı, fennel, rakı otu (TR) & $\begin{array}{l}\text { Muğla, } \\
\text { Menteşe }\end{array}$ & Fv & MUH 549 \\
\hline Cichorium intybus L. & $\begin{array}{l}\text { Hindiba, hindibağ, hindibahar, } \\
\text { güneğik, aslan pençesi, tavuk } \\
\text { ayağı, radika, (TR) }\end{array}$ & $\begin{array}{l}\text { Muğla, } \\
\text { Marmaris }\end{array}$ & $\mathrm{Ci}$ & MUH 309 \\
\hline $\begin{array}{l}\text { Liquidambar orientalis } \\
\text { Mill. }\end{array}$ & Sığla, günlük (TR) & $\begin{array}{l}\text { Muğla, } \\
\text { Köyceğiz }\end{array}$ & Lo & MUH 586 \\
\hline $\begin{array}{l}\text { Brassica oleracea var. } \\
\text { capitata } \mathrm{L} .\end{array}$ & $\begin{array}{l}\text { Cibez, lahana patlağı, lahana } \\
\text { filizi, lahana keli, azman (TR) }\end{array}$ & $\begin{array}{l}\text { Muğla, } \\
\text { Ortaca }\end{array}$ & Boc & MUH 1241 \\
\hline
\end{tabular}

\subsection{The Soil Characteristics of the Localities in which the Species Are Spread and Plant Nutrient Determination Studies}

In soil samples; the structure (sand, clay, silt ratio) was determined by hydrometer method; lime was determined calcimetrically by organic matter quantity method [13], receivable $\mathrm{Zn}, \mathrm{Fe}, \mathrm{Mn}$ and $\mathrm{Cu}$ were determined according to the DTPA method (diethylenetriamine-penta-acetic-acid) [14], receivable $\mathrm{K}, \mathrm{Ca}$ and $\mathrm{Mg}$ content [15] and receivable $\mathrm{Na}$ content [16] were determined in the extracts obtained with $1 \mathrm{~N}$ neutral ammonium acetate solution on atomic absorption spectrophotometer. Besides, Water Soluble Phosphorus content was determined in a calorimetrically on the spectrophotometer according to the Bingham [17] method. Receivable $\mathrm{B}$ by the plant in the soil was made according to $0,01 \mathrm{M}$ mannitol+CaCl 2 extract method and the amount of B was determined in the ICP-OES device [18], while $\mathrm{pH}$ and $\mathrm{EC}$ were determined by the combined $\mathrm{pH}-\mathrm{EC}$ meter. The total nitrogen in soil samples was determined by Kjeldahl method.

Macro and micro element analyses of the plant nutrient contents were performed in the ICP-OES device by using a separate wavelength specific for each element according to the method determined by Kacar [19]. The results were given as \%, ppm and ppb according to dry matter principle.

\subsection{The Use of the Plants in the Kitchen and Local Dishes}

As a result of the interviews with the local people in Menteşe, Bodrum, Marmaris, Fethiye, Ortaca, Datça, Dalaman, Köyceğiz, Seydikemer, Milas, Ula, Yatağan and Kavaklidere districts of Muğla province, the women having been living there for many years or since birth and who were experienced in making local dishes and getting to know herbs from nature, were determined by random sampling. Face-to-face interviews were made with these women between the dates of 16 May 2018 and 30 June 2018 within the framework of the semistructured interview form prepared previously. 59 interviews were made in total; 6 of which were in Bodrum, 3 were in Dalaman, 3 were in Datça, 6 were in Fethiye, 3 were in Kavaklidere, 3 were in Köyceğiz, 5 were in Marmaris, 7 were in Menteşe and in the center of Muğla, 6 were in Milas, 6 were in Ortaca, 3 were in Seydikemer, 2 were in Ula and 6 were in Yatağan. Each interview lasted for about 50-60 minutes. In the interview form, there were questions regarding the use and cooking method of the herbs determined for the research, their frequency and period of use, the place from which they were obtained, their effects on health that were known, and whether the women used a storage method that would ensure them to be used outside the season. The photos of these herbs were taken during the study, and while some of them were cooked by the participants, some others were tried to be cooked by the researcher in accordance with 
the given recipes. Descriptive analysis, which is one of the qualitative research methods and which enables the findings to be presented by summarizing and interpreting, was preferred as the research method.

\section{RESULTS and DISCUSSION}

\subsection{The Determination of the Soil Characteristics on Which the Species Are Spread}

As a result of the analyses performed, some of the physical and chemical characteristics of the localities on which the species spread was given in Table 2. When the soil characteristics of the localities on which the species were spread was evaluated in general, it was determined by analyses performed that all the plant species were spread between $\mathrm{pH}$-mild acid and neutral, in loamy, salt-free environment. When the lime contents of the locations were examined, it could be seen that all the plant species in the research preferred low-lime soils. It was also determined as a result of the soil analyses of the plants in the research that the soil of Brassica oleracea var. capitata species had the lowest organic matter content with $1.94 \%$, while the soil of Cichorium intybus species had the highest organic matter content with 3.24\% (Table 2).

Table 2. The findings regarding the soil analysis of the localities on which the species are spread

\begin{tabular}{llcccc}
\hline Parameters & & $\mathrm{Fv}$ & $\mathrm{Ci}$ & Lo & Boc \\
\hline Saturation & & 42.00 & 50.00 & 45.00 & 40.00 \\
EC $\left(\mathrm{dS} \mathrm{m}^{-1}\right)$ & & 0.81 & 1.19 & 0.28 & 0.80 \\
\% Salt & & 0.02 & 0.04 & 0.01 & 0.02 \\
$\mathrm{pH}$ & 6.81 & 6.56 & 6.73 & 6.84 \\
Lime (\%) & & 0.73 & 1.36 & 12.10 & 0.64 \\
Organic Matter (\%) & 3.04 & 3.24 & 2.35 & 1.94 \\
Nitrogen (N) (\%) & & 0.15 & 0.16 & 0.12 & 0.10 \\
& Phosphorus (P) & 28.00 & 11.00 & 12.00 & 19.00 \\
\multirow{4}{*}{ Macro Elements } & Potassium (K) & 58.78 & 420.87 & 248.51 & 82.54 \\
(ppm) & Calcium (Ca) & 2883.70 & 11960.93 & 13580.01 & 2604.52 \\
& Magnesium (Mg) & 2048.17 & 396.02 & 307.95 & 2291.39 \\
& Sodium (Na) & 36.67 & 20.97 & 75.66 & 148.34 \\
& Iron (Fe) & 42.88 & 47.57 & 51.42 & 42.91 \\
Micro Elements & Manganese (Mn) & 30.32 & 98.54 & 84.26 & 32.26 \\
(ppm) & Zinc (Zn) & 0.40 & 1.04 & 0.48 & 0.38 \\
& Copper (Cu) & 2.34 & 2.93 & 2.16 & 2.86 \\
\hline
\end{tabular}

*Fv: Foeniculum vulgare, Ci: Cichorium intybus, Lo: Liquidambar orientalis, Boc: Brassica oleracea var. capitata

In addition to this, the total nitrogen content of the soils of the plants in the research was the lowest in Brassica oleracea var. capitata species with $0.10 \%$, while it was the highest in Cichorium intybus species with $0.35 \%$ in capitate type (Table 2). Chapman [20] reported that the $\mathrm{N}$ limit value recommended to be present in the soil in terms of plant development should be between $0.11-0.15 \%$. Considering the reference ranges, when the total nitrogen contents of the soils on which all the research plants were grown were evaluated, it could be seen that they were between the reference values.

When the other soil macro element contents of the localities on which all the species mentioned were gathered were considered, it was determined by the analyses that $\mathrm{P}$ content 
(11-28ppm) was among K (58.78-420.87 ppm), Ca (2604.52-13580.01 ppm), Mg (307.95$2291.39 \mathrm{ppm})$ and $\mathrm{Na}(20.97-148.34 \mathrm{ppm})$ (Table 2). It was revealed that soil P contents on which the plant species other than Foeniculum vulgare species, which was one of the species in the research, were grown were sufficient. When the adaptable Potassium contents of the soils of the plants in the research were analyzed, it was determined that the lowest ratio was in the soil of Foeniculum vulgare species, whereas the highest ratio was in the soil of Cichorium intybus. According to literature, the K values accepted in the soils are between 201 and 250 ppm [21]. In our study, the Potassium contents in the soils of Cichorium intybus species were found to be higher when compared to the other plants. Considering the limit values, while the $\mathrm{Ca}$ values of the soils of Foeniculum vulgare and Brassica oleracea var. capitata species analyzed were found to be sufficient, the soil contents of the other plant species in our study were found to be at very high levels. When the limit values were taken into consideration, it was determined that $50 \%$ of the plant soils analyzed were sufficient, while $50 \%$ contained too much magnesium [21]. When the sodium contents of the soils were analyzed in general, it was revealed by the analyses that they were below the recommended limit values.

In the soils of the plants in the research, it was found out that the useful Iron (Fe) contents of the microelements were the lowest in the soil of Foeniculum vulgare species (42.88 ppm), while they were the highest in the soil of Liquidambar orientalis species (51.42 ppm). According to Lindsay and Norvell [14], the useful Fe value recommended was between 6 and $10 \mathrm{ppm}$, and when this value range was examined, it was revealed by the analyses that the iron concentration was high in all the soils analyzed in the research. While the receivable Manganese (Mn) content varied between 30.32-98.54 ppm, the mean value was found as $61.35 \mathrm{ppm}$ (Table 2). According to these limit values, it could be said that receivable Mn element was sufficient in the soil with a $90 \%$ ratio and high in the soil with a $10 \%$ ratio. When the Zinc ( $\mathrm{Zn}$ ) concentrations were examined, it was found that they were the lowest in the soil of Foeniculum vulgare species with $0.40 \mathrm{ppm}$ value and the highest in the oil of Cichorium intybus species with $1.04 \mathrm{ppm}$ (Table 2). When the soils analyzed were compared with the determined $\mathrm{Zn}$ sufficient level (0.8-2.5 ppm), it was revealed that there was no insufficiency in the soils of Cichorium intybus species in terms of receivable $\mathrm{Zn}$, whereas all the other soils were insufficient in terms of $\mathrm{Zn}$ content. Finally, it was reported that the sufficiency level of the receivable Copper $(\mathrm{Cu})$ content, which was another micro element in the soil, was $>0.2 \mathrm{ppm}$ and therefore, it was determined according to this recommended value that all the soils were sufficient in terms of $\mathrm{Cu}$ content [14].

\subsection{The Determination of the Species' Plant Nutrient Element Contents}

In order to reveal the nutritional status of the 4 naturally spreading edible plant species in Muğla province, mineral substance contents of the plant parts used in gastronomy were investigated. The changes in the macro element contents of the species were shown in Table 3.

When the nitrogen content of the edible parts of the plants in our study was considered, it was determined that the $\% \mathrm{~N}$ content was the lowest in Liquidambar orientalis plant $(2.27 \%)$, while the $\% \mathrm{~N}$ content was the highest in Foeniculum vulgare species (5.37\%). The average $\mathrm{N}$ ratio of the edible parts of the samples was determined as $3.74 \%$ (Table 3 ). The $\% \mathrm{~N}$ reference value determined by Kacar and Katkat [22] was between 1.5-5 and it was observed in the analyses within the scope of the research that the nitrogen content of Foeniculum vulgare plant sample was at a high level, whereas the nitrogen contents of the other plants in the study were between the recommended reference intervals. Similar to our study, Korkmaz et al. [23] reported that the nitrogen contents in some medicinal and aromatic plants (laurel, chamomile, nettle, yarrow, centaury and linden) ranged from $1.41 \%$ to $3.78 \%$. In another study, the nitrogen contents of 29 medicinal and aromatic plants that were mostly consumed in Greece ranged from $0.14 \%$ to $3.24 \%$ [24]. In the light of the literature reviewed, it could be noted that there was a 
quite wide variation in medicinal and aromatic plants in terms of the nitrogen content and that it was compatible with the nitrogen contents obtained in this study.

Table 3. Macro and micro element contents of the species' edible parts

\begin{tabular}{llcccc}
\hline \multicolumn{2}{c}{ Parameters } & Fv & Ci & Lo & Boc \\
\hline Macro Elements (\%) & Nitrogen (N) & 5.37 & 4.51 & 2.27 & 2.80 \\
& Phosphorus (P) & 0.41 & 0.36 & 0.22 & 0.38 \\
& Potassium (K) & 3.39 & 2.13 & 1.10 & 2.48 \\
& Calcium (Ca) & 2.61 & 1.92 & 0.46 & 9.07 \\
& Magnesium (Mg) & 0.36 & 0.18 & 0.45 & 0.58 \\
Micro Elements (ppm) & Iron (Fe) & 509.29 & 158.95 & 247.71 & 13621.24 \\
& Manganese (Mn) & 24.84 & 30.61 & 36.95 & 47.16 \\
& Zinc (Zn) & 58.06 & 33.05 & 49.12 & 260.35 \\
& Copper (Cu) & 47.34 & 26.81 & 28.79 & 67.82 \\
& Boron (B) & 32.12 & 27.20 & 12.93 & 20.17 \\
\hline
\end{tabular}

*Fv: Foeniculum vulgare, Ci: Cichorium intybus, Lo: Liquidambar orientalis, Boc: Brassica oleracea var. capitata

The \% P scopes revealed in this study seemed to vary between 0.22 (Liquidambar orientalis) and 0.41 (Foeniculum vulgare) (Table 3). Since the \% P value determined in the plant was between the limit values $(0.20-0.75 \%)$, there were no drawbacks [22]. In a study conducted, the phosphorus content in 8 medicinal and aromatic plants widely used by public in South West Nigeria exhibited a wide variation and that it varied between 100-3500 ppm [25]. In another study, it was stated that The P content of some members of the Lamiaceae family (thyme, rosemary, lavender, sage, basil and melissa) ranged from $0.07 \%$ to $0.34 \%$ [26]. Considering the $\mathrm{P}$ content in our study, it could be stated that it was supported by the literature mentioned above. The $\mathrm{K}$ content was measured the lowest in Liquidambar orientalis plant $(1.10 \%)$ and the highest in Foeniculum vulgare plant (3.39\%) (Table 3). In a study conducted, it was stated that the amount of potassium in mallow, chicory, wild asparagus, worm seed, fennel, poppy and crook, which were consumed as vegetables in the Aegean Region, varied between $0.29-0.58 \mathrm{mg} 100 \mathrm{~g}^{-1}$ [27]. In another study, it was determined that the amount of potassium of the wild plants in the region of Kilis and Gaziantep varied between 2.5-3\% [28]. These results coincide with the results of our study. While the Ca content of the species in our study was the lowest in Liquidambar orientalis species with a value of $0.46 \%$, it was highest in Brassica oleracea var. capitata species with a value of $9.07 \%$ (Table 3). Low and high values were determined according to the \% Ca reference interval (1-3\%) determined by Kacar and Katkat [22]. This is thought to be due to the climatic and topographic characteristics of the region. Of the studies with similar findings; Ashraf, Hayat, and Mumtaz [29] found that calcium content of the 17 endemic species they studied in their research from Artemisia to Pakistan was between $0.057-1.069 \%$. In another study, the calcium content of 10 medicinal plants grown in the north-east of India was examined and it was reported that there was a wide variation with the limits between 0.166-3.20\% [30]. Finally, considering the Mg content of the edible parts of the plants in our study, it was determined that the lowest Mg content was in Cichorium intybus species $(0.18 \%)$, while the highest $\mathrm{Mg}$ content was in the edible parts of Brassica oleracea var. capitata species $(0.58 \%)$ (Table 3$)$. Considering the results of the analysis we performed, it was determined that the $\mathrm{Mg}$ contents were close to the \% $\mathrm{Mg}$ reference interval $(0.25-1 \%)$ determined by Kacar and Katkat [22]. It was also found that the magnesium content was between $0.0117-0.114 \%$ in some of the spices and medicinal plants [31], and between 0.03$2.293 \%$ in some wild vegetables [32]. 
In addition to this, together with the fact that the microelements are the mineral elements that have a wide range of biochemical functions in living organisms and are vital for human health, they can have harmful effects when taken in high concentrations [33].

In this study, the lowest Fe content of the plant samples was determined in Cichorium intybus species with 158.95 ppm, while the highest Fe content was determined in Brassica oleracea var. capitata species with $13621.24 \mathrm{ppm}$. (Table 3). The reference level for iron in the plants was reported as 50-250 ppm [22]. Considering the limit values, the Fe content determined for Cichorium intybus and Liquidambar orientalis plant species were between the recommended values, whereas the Fe content of the other plants were quite high. In a similar study, Baydar and Erdal [34] examined the effects of plant growth regulators on the leaf quality of Izmir thyme (Origanum onites L.) (Fe: 47.25-97.50 ppm) and reported that the plants had high iron contents. In another study, it was also reported that the iron content in the 12 medicinal and aromatic plants obtained from the herbalists in Ordu, Samsun and Giresun provinces in the Black Sea Region of Turkey varied between 93 ppm (yarrow) and 105.3 ppm (basil) [35]. The literature studies given above seem to support our findings. Considering the Mn contents, it was determined that Foeniculum vulgare was $24.84 \mathrm{ppm}$ and Brassica oleracea var. capitata was $47.16 \mathrm{ppm}$ (Table 3). The reference level for manganese in the plants was reported as 25-200 ppm [22]. Meraler [36] noted that the mahaleb plant had differences in terms of manganese content compared to the parts of the plants investigated. The highest Mn content was found in the leaves of the mahaleb (36 ppm), while the lowest Mn content was found in the resin part of the mahaleb $(8 \mathrm{ppm})$. As a result of the research on the plants growing naturally in Ordu province and its region and consumed as vegetables, it was determined that the manganese content of the plants was between 21.40-77.40 ppm [37]. When the $\mathrm{Zn}$ content was examined, it was revealed that the lowest was in Cichorium intybus plant with $33.05 \mathrm{ppm}$ and the highest was in Brassica oleracea var. capitata with $260.35 \mathrm{ppm}$. (Table 3). The reference level for zinc in the plants was reported as 25-150 ppm [22]. The plants were also reported to have normal values in terms of zinc other than Brassica oleracea var. capitata plant samples. In the study where the mineral contents of some plants used as spices in Turkey were examined, it was found that $O$. vulgare contained $19.3 \mathrm{ppm}$ of $\mathrm{Zn}$ [38]. In the study examining some biological and ecological properties of Origanum (Lamiaceae) species endemic for Antalya province, it was reported that the annual average zinc contents of $O$. solymicum P.H. Davis, O. husnucanbaseri H. Duman, O. bilgeri P.H. Davis, O. minutiflorum O. Schwarz \& P.H. Davis plants that belonged to Origanum species were $14.5 \mathrm{ppm}, 31.75 \mathrm{ppm}, 38.75 \mathrm{ppm}$ and $32.75 \mathrm{ppm}$, respectively [39]. It was also determined as a result of the analyses performed on the plants obtained in the research areas that the $\mathrm{Cu}$ content was the lowest in the edible parts of Cichorium intybus plant (26.81 ppm), whereas it was the highest in the edible parts of Brassica oleracea var. capitata plant (67.82 ppm) (Table 3$)$. In the study that examined 30 medicinal plants in Kayseri [40], it was determined that there was a very wide variation between copper content 3.32 (jujube)-30.2 $\mathrm{gg} \mathrm{g}^{-1}$ (basil). A similar result was obtained by Şekeroğlu et al. [41] in terms of the copper content in the wild plants consumed as vegetables in Ordu province and it was determined that copper ratios ranged from 2.7 to $21.3 \mathrm{ppm}$. The reference level for copper in plants was reported as 6-30 ppm [22]. It was stated that toxic effects were detected when the copper content in plants was more than $20 \mathrm{ppm}$ [42]. In this respect, our study is in accordance with the literature. When the boron (B) contents were examined, it was noted that Liquidambar orientalis (12.93 ppm) was below the recommended limit values (20-60 ppm) [22]. In the study by Turan [43], it was reported that avocado (78 ppm), golden rod (39 ppm), comfrey (33 ppm) had the highest mean boron ratios in their plant leaves, whereas pilewort (1.55 ppm), bistort $(0.25 \mathrm{ppm})$ and green tea $(0.07 \mathrm{ppm})$ had the lowest mean boron ratios in their plant leaves, respectively. In another study, it was reported that the mean boron ratio was the highest in alcea (16 ppm), sage (16 ppm) and hop (14 ppm) plants, whereas it was the lowest in chamomile (7.5 
ppm), yarrow $(6.9 \mathrm{ppm})$ and cassidony $(5.8 \mathrm{ppm})$ plants. Among the root/rhizome plants examined, the highest mean boron ratio was found in mullein (13.156 ppm), nip (11.2 ppm) and cocklebur $(7.9 \mathrm{ppm})$ plants, whereas the lowest boron ratio was found in least galangal (0.95 ppm), turmeric (0.7 ppm) and ginger (0.6 ppm) plants [44].

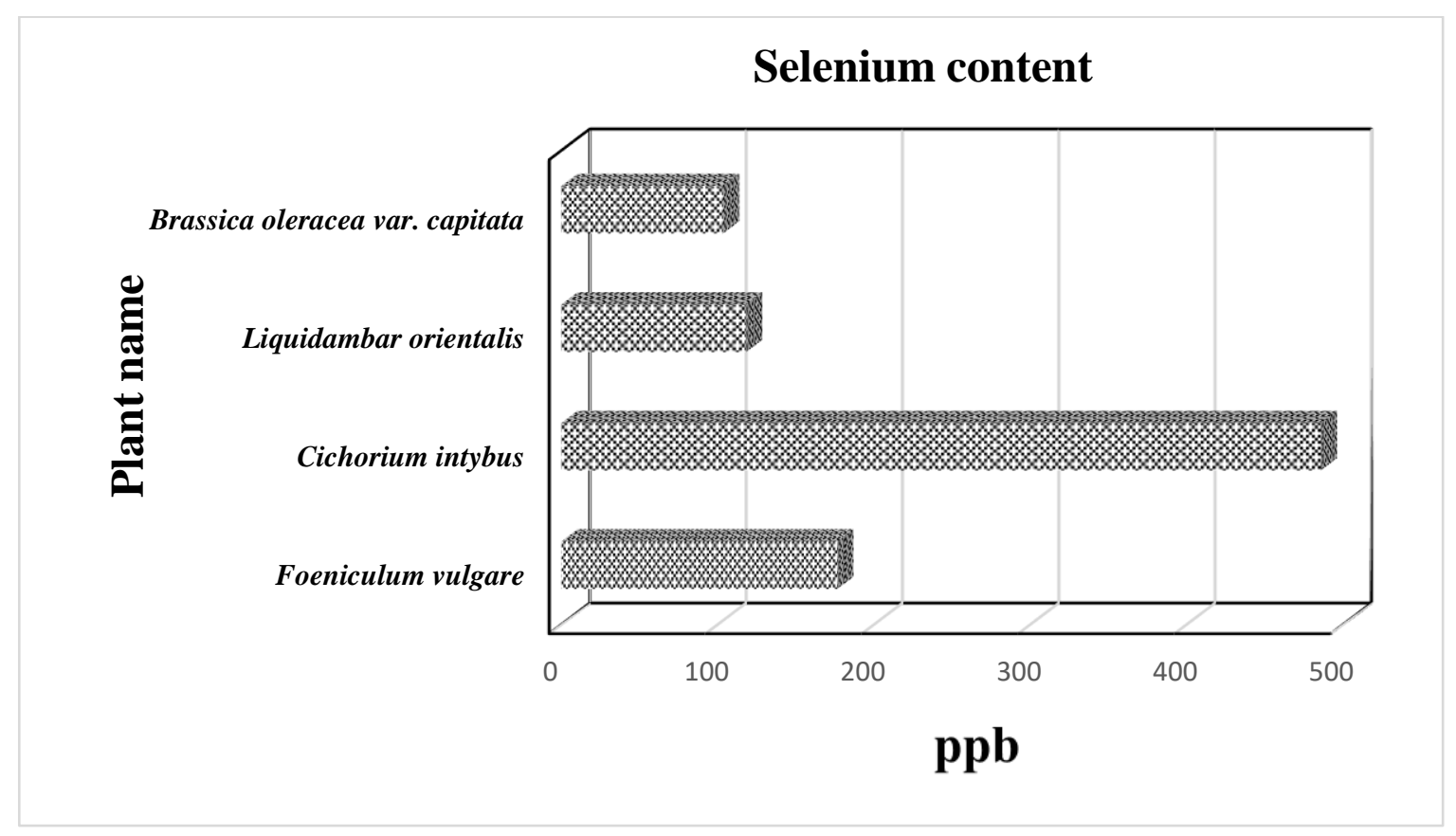

Figure 1. Se contents of the edible parts of the species

Selenium, whose certain necessity in plants is a matter of discussion, is an absolutely necessary element for animals and humans $[45,46]$. Selenium, which is vital for human health, is an essential mineral for the proper functioning of the thyroid gland and also plays an important role as in the antioxidant defense as an enzyme cofactor. The recommended daily amount of Se intake for humans has been reported as $55 \mu \mathrm{g}_{\text {per day }}{ }^{-1}$ [47]. When Se contents of the edible parts of the species were examined, it was determined that Brassica oleracea var. capitata species had the lowest Se content (103.42 ppb), whereas there was approximately 5.5 times more Se content in the leaves of Cichorium intybus species (485.82 ppb) (Figure 1). In the study by Şimşek [48], it was reported that the Se content of the 4 wild plant species (nettle, kaldir (TR), cat brier, sakarca (TR)) obtained from 10 different locations in Ordu province and its region varied between $0-76 \mathrm{ppb}$. Besides, in the study on the nutritional status of the 7 edible plants in Niger, it was suggested that the lowest Se content was found in Corchorus tridens L. plant $\left(14.9 \mu \mathrm{g} \mathrm{g}^{-1}\right)$, while the highest Se content was found in Maerua crassifolia Forssk. plant (33.9 $\mu \mathrm{g} \mathrm{g}^{-1}$ ) obtained from Maradi region [49]. In the light of these data, it was determined that the Se contents in our samples were high and low according to the literature.

\subsection{The Findings Obtained from the Interviews with the Local People in Terms of Gastronomy}

In the interviews, the participants were asked about the use and cooking method of each plant in the research, how often they were used, whether they had a local name, where they were obtained from, whether anything was done in order to keep them for a long time, and their known benefits for health. The data obtained were evaluated and recorded in the written form. 


\subsubsection{The Recipes of Arapsaçı Herb and Related Research Findings}

In the interviews made in all the districts of Muğla province, the participants expressed that the smell of arapsaçı, whose local name was called "sıra", was like aniseed and those who did not prefer a very intense aroma stated that they did not use it alone. It is used in artichokes with olive oil, in broad bean dishes by chopping in order to give flavor, and by adding into the herb mixtures prepared for pastries. In addition to this, the participants who enjoyed the taste and smell of it stated that they consumed it by cooking with lamb meat, and with onions and eggs, or by mixing with dry cottage cheese at breakfast. It was also stated that the best time of arapsaçı, which grew naturally in the fields and gardens, was in March-April, and that it was good for urinary tract disorders and cancer. Since its seeds were good for gas pains, it was expressed that the plant and its seeds were used by drying when it was not the season. In the interviews made in Fethiye district, the participants also stated that they prevented gas pains by using it in dry beans. It was believed that it was good for the heart, lowered cholesterol and was said to be good for insomnia and feel relieved if it was boiled and its water was drunk. "Sira", which was mentioned as the indispensable part of herb dishes, was also said to go with the dishes with olive oil, stuffed grape leaves and stuffed vegetables. Arapsaçı grows naturally in the mountains, water-lands and gardens especially in February-March-April, and can always be found in the street markets. The plant, whose kinds are called "wise" and "crazy" can also be obtained in nature or by planting in the garden. One interviewee stated that they knew it as "sıra", "fennel" or "rakı otu".

In accordance with the interviews, it can be said that arapsaçı is used in many dishes as a fresh spice due to its aromatic effect. It was observed that it was used while preparing the mixtures of pastries and cooking olive oil dishes like broad beans, and in local herb frying dishes. Apart from being a subsidiary aromatic ingredient, some of the examples of the recipes obtained as a result of the research are as follows;

\section{Arapsaçı with Lamb Meat}

Ingredients: $1 / 2 \mathrm{~kg}$ arapsaçı ( 2 bunches), $250 \mathrm{~g}$ lamb meat (chopped), 1 onion, 1 glass (small tea glass) of olive oil, salt, 1 tablespoon flour, juice of 1 lemon

Preparation: The meat is fried until it releases its water and then boils down. Olive oil and chopped onion are added. After arapsaçı is washed, its stem and leaves are cut separately. Chopped stems are added into the meat and onion, and it continues to be fried. Then, the leaves are added and salt is added with enough hot water over the mixture. When it boils, the sauce prepared in a separate bowl with flour, lemon juice and water of the dish is added gradually by stirring. It is cooked on medium heat for about ten minutes with the lid closed.

PS: The same dish can also be made with the stems and tomato paste only. Sauce is not used in the sauced one.

\section{Arapsaçı with Dry Cottage Cheese (for Breakfast)}

Ingredients: 1 bunch of arapsaçı (leaves only), 1 large bowl of dry cottage cheese, salt, pepper, powdered red pepper, 2-3 spoons of olive oil

Preparation: Arapsaçı is washed and chopped. All the ingredients are added in it and mixed. It is consumed at breakfast.

\section{Arapsaçı with Milk}

Ingredients: 1 onion, $1 / 2$ tea glass of olive oil, $1 / 2 \mathrm{~kg}$ arapsaç1, 1 tea glass of bulghur, salt, powdered red pepper, $1 / 2 \mathrm{~kg}$ milk

Preparation: Onion is chopped and fried. Chopped arapsaçı, powdered red pepper (optional) and bulghur is added in it, and it continues to be fried. Bulghur is cooked by adding a little hot water and boiling down. Until this stage, salt is not added as it is not desired that salt 
sours the milk. When hot milk is added and it is boiled once again, salt is added. It is rested with the lid closed.

\subsubsection{The Recipes of Hindiba Herb and Related Research Findings}

It is known that the plant whose leaves are consumed is especially rich in vitamin C $[27$, 50]. Hindiba, which is known and used as salad, is also consumed by frying with onions and eggs after boiling. It was stated that it was good for the stomach and it prevented stomach bloating, it was diuretic and good for the liver and cancer. It was also noted that hindiba, which was also known as "redshank herb" in Milas and Yatağan districts, was boiled and served as salad with syrup and garlic. It was said to be good for stomach and gallbladder and melted the stones in the gallbladder. In Kavaklidere, together with the name "redshank herb", it was also called as "tavukayağı" and "radika". In central Muğla, it was seen that both entitling and uses differed. In Menteşe, it is known with many names like "hindibağ", "hindibahar", "güneğik" and "aslanpençesi". Though it was stated to be mostly boiled and served as salad with syrup, it was also fried with onions or eggs and cooked as a dish with bulghur. It was also said that the sour orange was ideal for the syrup and that by crunching (frying) dry pepper, it was put on it. The recipes and research findings regarding the herb that is said to be one of the herbs always found in the street markets are as follows;

\section{Hindiba Salad}

Ingredients: $1 / 2 \mathrm{~kg}$ of hindiba, $1 / 2$ tea glass of olive oil, 1-2 cloves of garlic, salt, lemon juice (or pomegranate syrup)

Preparation: Hindiba is boiled in the boiling water for 3-4 minutes. It is drained in cold water and then, chopped up. It is flavored with lemon juice or pomegranate syrup, olive oil and crushed garlic and salt.

\section{Hindiba with Syrup}

Ingredients: $1 / 2 \mathrm{~kg}$ hindiba, 1 tea glass of olive oil, 2-3 spoons of pomegranate syrup (or 1/2 lemon), 2-3 cloves of garlic, salt

Preparation: Washed and sorted hindiba is put in the boiling water as a whole. 3-4 minutes later, it is drained, cooled and chopped. A sauce is prepared with crushed garlic, pomegranate syrup, salt and olive oil. Hindiba is added into the sauce and rested until it is flavored. It is served cold.

\subsubsection{The Recipes of Cibez and Related Research Findings}

In the region, it is known as "lahana patlağı" or "azman". It is cooked by boiling and frying it with a lot of onions and consumed fresh, which is caused by the fact that it can be easily found in the gardens. In Bodrum, their photos were shown to the participants when they did not know it by the name. However, some of them expressed that they did not know what cibez was, and some others stated that they did not know it as cibez, but as "lahana patlağı", "lahana filizi" or "lahana keli". They also stated that they boiled and fried it, made stuffed dishes and salads by boiling. It was said to be good for gas pains, diabetes and edema. It was noted that it was found easily in January, February and March, and also in spring. It was also said to be found in the gardens and greenhouses, and therefore, consumed fresh. It was expressed that it was also known as "azman" in Fethiye district.

Cibez, which is among the most commonly used herbs in Cretan cuisine, is known as the new shoots that are formed in the cut after the harvest of cabbage or broccoli [51]. The recipes and research findings regarding Cibez are as follows; 


\section{Cibez Salad}

Ingredients: $1 / 2 \mathrm{~kg}$ of cibez, $1 / 2$ tea glass of olive oil, 1-2 cloves of garlic, salt, lemon juice (or pomegranate syrup)

Preparation:Cibez is boiled in the boiling water for about 3-4 minutes. It is drained in cold water and then, chopped up. It is flavored with lemon juice or pomegranate syrup, olive oil and crushed garlic and salt.

\section{Fried Cibez, (with or without Eggs)}

Ingredients: $1 / 2 \mathrm{~kg}$ cibez, 2 onions, 2 cloves of garlic, $1 / 2$ teaspoon of olive oil, 1 teaspoon of butter, 2 eggs, salt, pepper, powdered red pepper

Preparation: Onions and garlic are chopped up and fried with olive oil and butter. Boiled and chopped up cibez are added in it. It is flavored with salt, pepper and powdered red pepper. Eggs are added and cooked by stirring.

\section{Cibez Stew}

Ingredients: $1 / 2 \mathrm{~kg}$ of cibez, 2 onions, 1 spoon of tomato paste (red pepper and tomato together), 1 teaspoon of powdered red pepper, 1/2 cup of bulghur (rice may also be preferred), 1 teaspoon of olive oil, salt.

Preparation: The diced onion is sauted in olive oil. It is fried with tomato paste and powdered red pepper. Boiled cibez is added. After stirring, a glass of hot water is added. Then, bulghur and salt are added and cooked on low heat until bulghur softens up.

\subsubsection{The Recipes of Günlük Tree (Sı̆̆la) Leaves and Related Research Findings}

It was mentioned especially in Köyceğiz, Ortaca, Dalaman, Fethiye districts that the tree, which was named as "günlük" or "sığla" by the local people, was used to cook a dish from its fresh shoot leaves. Anatolian Sweetgum Tree (Liquidambar orientalis Mill.), which spreads endemically in Muğla province, is a perennial outdoor ornamental plant with a woody structure that sheds its leaves in winter $[52,53]$. It was the only plant among the plants in the research which was generally known by all the districts and expressed with a single cooking technique. As its leaves are thought to be beneficial due to its unique aroma and the benefits of its oil, it is thought to be cooked as a dish. The recipe of the "günlük" leaf cooked with bulghur in Muğla is as follows;

\section{Günlük (Siğla) with Yoghurt}

Ingredients: 1 bunch of günlük tree leaves, 2 leeks, 4-5 branches of "sıra" herb, 1 bunch of mixed herbs, salt, 1/2 cup of bulghur, 2 cloves of garlic, 2 glasses of yoghurt, 1 spoon of butter, $1 / 2$ tea glass of olive oil, powdered red pepper, dried hot pepper (optional).

Preparation:All the herbs are washed and boiled with a little water in such a way that they still remain fresh and then, chopped. The leeks are chopped up and fried with butter and a little olive oil. Boiled and chopped herbs are added into the fried leeks. Bulghur and salt are added and then, the mixture is stirred. 1 tea glass of water is added and it is cooked until bulghur softens up and boils down. Garlic is crushed in a bowl and mixed with yogurt. Herbs cooked with the garlic yogurt are mixed. Powdered red pepper or dried pepper is fried with oil in a separate pan and put over. It is served warm or cold.

\section{CONCLUSION}

Today, the use of herbal medicines in the treatment of diseases is increasing day by day, and therefore, related scientific fields and research have gained great importance. While new possibilities are being investigated in the treatment of diseases, intensive studies are carried out in order to prevent diseases and lead a healthy life. The most intensive studies in this regard are 
on nutrition. As a result of the examination of the macro and micro nutrients in the leaves of the plants, it was observed that the values obtained were generally in line with and in contrast to the literature. Together with the fact that a general nutritional status of the species investigated was revealed as a result of the study, it was also stipulated that more detailed researches should be conducted because the fact that the micro elements or heavy metals were above a certain limit value had a toxic effect on the plants and human health was revealed by various researches. In this regard, it was revealed by the literature research carried out and the data obtained that determining the mineral element contents in the plants could be beneficial for human health and nutrition.

It is possible to find the plants given in the study from nature in the districts of Muğla province as well as in the street markets brought by the sellers or cultivated. These herbs, which can be obtained from local markets, are generally cooked with similar cooking techniques. These techniques are souring, milking, frying with or without eggs, preparing like salad with syrup sauce, frying with bulghur, making it with yoghurt. These cooking styles are the unique cooking techniques of this region. The common pre-treatment is boiling with little water in such a way that it stays fresh without darkening.

It has similarities to the Cretan cuisine with its such properties as boiling herbs fresh, wishing to cook without darkening, using olive oil intensively. As well as the characteristics of its own local dishes, it is possible to explain this situation as that it is influenced by the Cretan cuisine due to the migrations experienced years ago.

It can be said that the herbs, which are well known and available in the street markets, are still being cooked but the herbs that do not have a culture or need to be collected are consumed less and even about to be forgotten. Indeed, the fact that the wild peas were not known by the participants in the interviews conducted in the places other than Bodrum is a proof for this situation.

The interviewees stated that hindiba was good for the stomach, prevented stomach bloating, diuretic, and was good for the liver and cancer disease. When the literature was examined, it could be noted that this finding coincided with the results of the study by Gül and Dinler [54] who stated that it was good for diabetes, liver and bladder stones. It was believed by the interviewees that arapsaçı was good for the heart and lowered cholesterol, and also said to relieve and be good for insomnia if it was drunk after boiling. In their study, Karaca, Y1ldirım, and Çakıc1 [55] expressed the benefits of arapsaçı as "good for the kidney stone, diabetes, bronchitis, chronic cough, gas pains and eye-strengthening, as well as facilitating digestion, soothing, preventing heart throbs, enhancing breast milk in the mothers breastfeeding their babies, and relieving stomachaches in the children". Therefore, it could be said to show similarities with what the participants said in terms of the effects of arapsaç1 on health. All these results coincide with the data we obtained as a result of the interviews. It was also stated that arapsaç1, which was locally called "sıra" was good for urinary tract disorders and cancer, and its seeds were good for gas pain. This finding could be said to be in line with the result obtained in the study by Kaya, Incekara, and Nemli [27], who expressed that the plant facilitated digestion, relieved the stomach and had a soothing effect as it contained nonpersistent gas and oil. The fact that it was used in all herb dishes and in the dishes made with olive oil just like a fresh spice rather than being used alone due to being an aromatic herb and having a sharp aroma was also mentioned in the study by Kaya, İncekara, and Nemli [27] as it was used for the same purpose in fish dishes and in "rakı" (a famous Turkish alcohol drink) production.

Unlike other cooking techniques, as the cooking technique called milking was not seen in the places other than Fethiye district and its region, and also in other studies, it could be considered to be new information and deemed necessary to be recorded. 
One of the mixtures they used as a sauce was the coloured sauce that they usually prepared with onions and tomato paste or powdered red pepper, or sometimes concentrated with flour and cooked by adding the main ingredients. The other was the sauce served by putting the boiled herbs prepared with olive oil, garlic and syrup (mostly pomegranate syrup, and also lemon juice, bitter orange juice or lemon salt), which they called syrup sauce. Another sauce was yoghurt with garlic. Besides, cooking with bulghur by frying with plenty of onions, which they could consume not only with the sauce but also without the sauce, was one of the most common techniques used. The other cooking technique preferred at least as much as cooking with bulghur was frying with onions and eggs. Olive oil was used in all the herb dishes.

Local people generally preferred to collect and consume the herbs freshly and believed that it should be consumed in the season as there were such a lot of herbs that they did not feel the necessity of storing them for a long time. The herbs growing naturally and obtained from the mountains or natural environments are thought to have a positive effect on health. However, due to the fact that most of these herbs are not available or are rare in the street markets, it is required to collect them, which lead to cooking these herb dishes less. The fact that they were cooked more in the past was also a finding obtained in many other studies. Obtaining these herbs from nature by providing their sustainability under controlled conditions and delivering them to people will enable the continuity of the culture of herb dishes.

\section{Acknowledgements}

This study has been granted by the Muğla Sitkı Koçman University Research Projects Coordination Office through Project Grant Number: (BAP-17/160).

\section{Declaration of Conflicting Interests and Ethics}

The authors declare no conflict of interest. This research study complies with research publishing ethics. The scientific and legal responsibility for manuscripts published in IJSM belongs to the author(s).

\section{Orcid}

Selma Atabey (D) https://orcid.org/0000-0001-7676-1760

Mahmut Yildiztekin (D) https://orcid.org/0000-0002-0206-0117

Atilla Levent Tuna (iD https://orcid.org/0000-0001-5123-0031

Okay Nazli (D) https://orcid.org/0000-0001-8500-5510

Olcay Ceylan (D) https://orcid.org/0000-0002-4435-8405

İbrahim Yokas (D) https://orcid.org/0000-0003-2501-7282

\section{REFERENCES}

[1]. Erik, S., Tarıkahya, B. (2004). Türkiye Florası Üzerine. Kebikeç, 17(1), 139-163.

[2]. Yaşar, Ü., Özyiğit, İ.İ. (2009). Use of human hair as a potential biomonitor for zinc in the Pendik District Istanbul Turkey. Rom Biotech Lett., 14(3), 4477-84.

[3]. Bakar, C., Baba, A. (2009). Metaller ve insan sağllğg: Yirminci yüzylldan bugüne ve geleceğe miras kalan çevre sağlığı sorunu. 1.Tıbbi Jeoloji Çalıştayı, 30 October-1 November, Ürgüp, Nevşehir, Turkey.

[4]. Carpenter, K., Kent-Jones, D.W., Truswell, A.S., Weininger, J. (2013). Human nutrition. Encyclopædia Britannica Online Academic Edition Retrieved 27.

[5]. Rayman, M.P. (1997). Dietary selenium: Time to act - Low bioavailability in Britain and Europe could be contributing to cancers, cardiovascular disease, and subfertility, Brit Med J., 314(7078), 387-388.

[6]. Lubiński, J., Marciniak, W., Muszynska, M., Jaworowska, E., Sulikowski, M., Jakubowska, A., Kaczmarek, K., Sukiennicki, G., Falco, M., Baszuk, P., Mojsiewicz, M., Kotsopoulos, 
J., Sun, P., Narod, S.A., Lubiński, J.A. (2018). Correction: Serum selenium levels and the risk of progression of laryngeal cancer. PLoS ONE, 13(3), ID:29304040 http://doi.org/10.1371/journal.pone.0194469.

[7]. Hartikainen, H. (2005). Biogeochemistry of selenium and its impact on food chain quality and human health. Journal of Trace Elements in Medicine and Biology, 18(4), 309-318.

[8]. Girling, C.A. (1984). Selenium in agriculture and the environment. Agriculture, Ecosystem and Environment, 11(1), 37-65.

[9]. Combs, G.F., Jr., Lu, J. (2001). Selenium as a cancer preventive agent. Selenium: Molecular Biology and Role in Health. Kluwer Academic, New York.

[10]. Hawkesford, M.J., Zhao, F.J. (2007). Strategies for increasing the selenium content of wheat. Journal of Cereal Science, 46(3), 282-292.

[11]. Davis, P.H. (1984). Flora of Turkey and the East Aegean Islands, 3rd ed.; Edinburgh University Press: Edinburgh, Scotland.

[12]. Davis, P.H., Mill, R.R., Tan, K. (1988). Flora of Turkey and the East Aegean Islands, 10th ed.; Edinburgh University Press: Edinburgh, Scotland.

[13]. Walkley, A., Black, I.A. (1934). An examination of the Degtjareff method for determining soil organic matter, and a proposed modification of the chromic acid titration method. Soil Science, 37(1), 29-38.

[14]. Lindsay, W.L., Norvell, W.A. (1978). Development of a DTPA soil test for zinc, iron, manganese and copper. Soil Science Society of America Journal, 42(3), 421-428.

[15]. Thomas, G.W. (1982). Exchangeable cations. Chemical and Microbiological properties. Agronomy Monograph, 9, 159-165.

[16]. Knudsen, D., Peterson, G.A., Pratt, P.F. (1982). Lithium, sodium and potassium. Methods of soil analysis: Part 2. Chemical and Microbiological Properties, 9, 225-246.

[17]. Bingham, F.T. (1982). Boron. Methods of Soil Analysis. Part 2. Chemical and Microbiological Properties, 9, 431-447.

[18]. Kacar, B., Fox, R.L. (1967). Boron status of some Turkish soils. University of Ankara, Yearbook of the Faculty of Agriculture, 1966, 99-111.

[19]. Kacar, B. (1992). Yapraktan bardağa çay. T.C. Ziraat Bankası Matbaası: Ankara, Turkey.

[20]. Chapman, H.D. (1973). Diagnostic criteria for plants and soils. University of California Office of Agricultural Publications: Berkeley California, the USA.

[21]. FAO. (1980). Soil and plant testing and analysis as a basis of fertilizer recommendations. Soils, FAO Bulletin, 38(2), 95.

[22]. Kacar, B., Katkat, A.V. (2007). Bitki Besleme. Nobel Yayın, 3. Press, Ankara.

[23]. Korkmaz, K., Kara, Ş.M., Akgün, M., Bat1, E. (2014). Determination of macro nutrient status in some medicinal plants from the Black Sea provinces in Turkey. In $8^{\text {th }}$ Conference on Medicinal and Aromatic Plants of Southeast European Countries, Durres, Albania, May 19.

[24]. Karagiannidis, N., Panou-Filotheoua, H., Lazari, D., Ipsilantis, I., Karagiannidou, C. (2010). Essential oil content and composition, nutrient and mycorrhizal status of some aromatic and medicinal plants of northern Greece. Natural Product Communications, 5(5), 823-830.

[25]. Lasisi, A.A., Ejelonu, B.C., Nwosu, F.O., Olayiwola, M.A., Yusuff, A.A. (2005). Heavy metals and macronutrient content in selected herbal plants of South-Western Nigeria. Int. J. Chem., 15(3), 147-154.

[26]. Kara, Ş.M., Özkutlu, F., Açıkgöz, M.A., Batı, E. (2014). Essential macro nutrient profiles of selected medicinal and aromatic plants from the family of Lamiaceae. In $8^{\text {th }}$ Conference on Medicinal and Aromatic Plants of Southeast European Countries, Durres, Albania, May 19. 
[27]. Kaya, İ., İncekara, N., Nemli, Y. (2004). Ege Bölgesi'nde sebze olarak tüketilen yabani kuşkonmaz, sirken, yabani hindiba, rezene, gelincik, çobandeğneği ve ebegümecinin bazı kimyasal analizleri. Yüzüncü Yıl Üniversitesi Tarım Bilimleri Dergisi, 14(1), 1-6.

[28]. Akgunlu, S.B. (2012). Mineral Content and microbiological analysis of some wild Edible vegetables consumed in Kilis and Gaziantep provinces. MSc. Thesis, Kilis 7 Aralık University Graduate School of Natural and Applied Sciences Department of Biology, Kilis, Turkey.

[29]. Ashraf, M., Hayat, M.Q., Mumtaz, A.S. (2010). A study on elemental contents of medicinally important species of Artemisia L. (Asteraceae) found in Pakistan. Journal of Medicinal Plants Research, 4(21), 2256-63.

[30]. Bhanisana Devi, R.K., Sarma, H.N.K. (2013). Profile of trace elements in selected medicinal plants of North East India. J. Appl. Phys., 4(3), 47-51.

[31]. Corlett, J.L., Clegg, M.S., Keen, C.L., Grivetti, L.E. (2002). Mineral content of culinary and medicinal plants cultivated by Hmong refugees living in Sacramento, California. International Journal of Food Sciences and Nutrition, 53(2), 117-128.

[32]. Turan, M., Kordali, S., Zengin, H., Dursun, A., Sezen, Y. (2003). Macro and micro mineral content of some wild edible leaves consumed in Eastern Anatolia. Acta Agriculturae Scandinavica, Section B-Plant Soil Science, 53(3), 129-137.

[33]. Gürel, M. (2014). Türkiye'de yaygın olarak kullanılan çeşitli tıbbi bitkilerin bazı makro ve mikro element içeriklerinin belirlenmesi. MSc. Thesis, Ordu Üniversitesi, Ordu, Turkey.

[34]. Baydar, H., Erdal, İ. (2004). Bitki büyüme düzenleyicilerinin İzmir kekiğinin (Origanum onites L.) yaprak kalitesine etkisi. Tartm Bilimleri Dergisi, 10(1), 9-13.

[35]. Açıkgöz, M.A., Karnak, E.E. (2013). Micro-nutrient composition of some medicinal and aromatic plants commonly used in Turkey. In the International Conference of the University of Agronomic Sciences and Veterinary Medicine, Bucharest, Romania, June 5.

[36]. Meraler, S.A. (2010). Determination of mineral composition in different plant parts of Mahaleb Cherry (Prunus mahaleb L.). MSc. Thesis, Kilis 7 Aralık University Graduate School of Natural and Applied Sciences Department of Biology, Kilis, Turkey.

[37]. Şekeroğlu, N., Özkutlu, F., Deveci, M., Dede, Ö., Y1lmaz, N. (2005). Ordu ve yöresinde sebze olarak tüketilen bazı yabani bitkilerin besin değeri yönünden incelenmesi. Türkiye VI. Tarla Bitkileri Kongresi, 5-9 September 2005, 1, 523-528, Antalya, Turkey.

[38]. Özcan, M. (2004). Mineral contents of some plants used as condiments in Turkey. Food Chemistry, 84(3), 437-440.

[39]. Ünal, O., Topçuoğlu, Ş.F., Gökçeoğlu, M. (2005). An investigation on biological characteristics of endemik Origanum species in Antalya. Akdeniz University Mediterranean Agricultural Sciences, 18(1), 1-14.

[40]. Tokatlıoğlu, Ş. (2012). Determination of trace elements in commonly consumed medicinal herbs by ICP-MS and multivariate analysis. Food Chemistry, 134(4), 2504-08.

[41]. Şekeroğlu, N., Özkutlu, F., Deveci, M., Dede, Ö., Yılmaz, N. (2006). Evaluation of some wild plants aspect of their nutritional values used as vegetable in eastern Black Sea Region of Turkey. Asian Journal of Plant Sciences, 5(2), 185-189.

[42]. Y1lmaz, R., Sakcalı, S., Yarc1, C., Aksoy, A., Ozturk, M. (2006). Use of Aesculus hippocastanum L. as a biomonitor of heavy metal pollution. Pak. J. Bot., 38(5), 1519-27.

[43]. Turan, SS. (2014). Determination of heavy metals and mineral elements in leaves of some widely used medicinal plants in our country. MSc. Thesis, Marmara University, Institute of Pure and Applied Sciences, İstanbul, Turkey. 
[44]. Çolak, C. (2014). Determination of heavy metal and mineral element in root and flowers of some medical plants widely use in traditional treatments in our country. MSc. Thesis, Marmara University, Institute of Pure and Applied Sciences, İstanbul, Turkey.

[45]. Miller, E.R., Lei, X., Ullrey, D.E. (1991). Trace elements in animal nutrition. In Micronutrients in agriculture. 2nd ed.; Morvedt, J.J., Cox, F.R., Shuman, L.M., Welch, R.M., Eds.; Soil Science Society of America Inc: Madison WI, the USA, pp. 593-662.

[46]. Campen Van, D.R. (1991). Trace elements in animal nutrition. In Micronutrients in agriculture. 2nd ed.; Morvedt, J.J., Cox, F.R., Shuman, L.M., Welch, R.M., Eds.; Soil Science Society of America Inc: Madison WI, the USA, pp. 663-702.

[47]. White, P.J., Broadley, M.R. (2005). Biofortifying crops with essential mineral elements. Trends in Plant Science, 10(12), 586-593.

[48]. Şimşek, A. (2010). Determination of mineral composition of some edible wild plant species grown in natural vegetation of Ordu province. MSc. Thesis, Ordu University, Institute of Natural and Applied Sciences, Ordu, Turkey.

[49]. Freiberger, C.E., Vanderjagt, D.J., Pastuszyn, A., Glew, R.S., Mounkaila, G., Millson, M., Glew, R.H. (1998). Nutrient content of the edible leaves of seven wild plants from Niger. Plant Foods for Human Nutrition, 53(1), 57-69.

[50]. Baytop, T. (1984). Türkiye'de bitkilerle tedavi: Geçmişte ve bugün. İstanbul University Press, İstanbul, Turkey.

[51]. Karaca, O.B., Yıldırım, O., Çakıcı, C. (2015). Girit yemek kültürü ve sürdürülebilirliği. Journal of Tourism and Gastronomy Studies, 3(1), 3-13.

[52]. Çetinkale Demirkan, G. (2015). The effects of sewage sludge applications on several tree species. Çukurova University, Institute of Natural and Applied Sciences, Department of Landscape Architecture, Adana, Turkey.

[53]. Akat, H., Şahin, O., Çetinkale Demirkan, G., Akat Saraçoğlu, Ö. (2017). Süs Bitkileri Üretim Teknikleri. Efil Yayınevi. Ankara, ISBN: 978-605-4160-66-2.

[54]. Gül, V., Dinler, B. (2016). Some Medical and Aromatic Plants Growing Naturally in Kumru Region (Ordu). Süleyman Demirel University Journal of the Faculty of Agriculture, 11(1), 146-642.

[55]. Karaca, O.B., Yıldırım, O., Çakııı, C. (2015). An Evaluation on Their Relation to Health and Wild Plant Meals, Wild Edible Plants in Gastronomy Tourism. Journal of Tourism and Gastronomy Studies, 3(3), 27-42. 